Strabismus 0927-3972/95/US\$ I0.50

Strabismus-199.5, Vol. 3, No. 3,

pp. I3I-I42,

(C) Eolus Press

Buren (The Netherlands) 1995

Accepted Io July I 995

\section{The Early vs. Late Infantile Strabismus Surgery Study: Monitoring Report}

\author{
The Early vs. Late Infantile Strabismus Surgery Study Group
}

\begin{abstract}
The Early vs. Late Infantile Strabismus Surgery Study Group is a group of strabismologists and orthoptists who investigate whether early or late surgery is preferable in infantile strabismus, in a non-randomized, prospective, multi-center trial. Infants between six and I 8 months of age will receive a standardized entry examination and then be operated either before their second anniversary, in clinics A, or between 32nd and 6oth month of age in clinics B. The children will be evaluated at age six. After completion of the study, the two groups can then be compared regarding degree of binocular vision, angle of strabismus and visual acuity of the worse eye relative to the better one. This is the second monitoring report of the study.
\end{abstract}

\section{Key words Strabismus; surgery}

Preliminary remark The analysis for this monitoring report was performed in April 1995. All Registration and other forms that reached the study before April I t th were included in the analysis.

Please note: Throughout the report we use the designation entered to characterize patients who are included into the study, monitored and evaluated at age six.

For all children with infantile, convergent strabismus age six to I 8 months referred to a participating clinic for the first time, an Entry Examination form and an Examination form must be filled out, even if any of these children is further excluded from the study for any reason. Data on children who might have taken part but did not do so for any reason, must be obtained to get an impression of what is excluded and what is included in each participating clinic. Accordingly, the designation excluded is used throughout this report to indicate all patients who were excluded and not entered into the study thereafter. All entered and excluded children are registered.

1 Participants Originally, 84 clinics from I4 countries did send a letter of intent to participate in the study. Forty-one of these elected to take part in the early surgery group and 43 in the late surgery group. They have been listed in the last year's monitoring report (The Early vs. Late Infantile Strabismus Surgery Study Group, I 994). Unfortunately, only 55 of these (33 in the late and 22 in the early surgery group) have become active, i.e., did register children at the study center.
Correspondence to: Uwe Haag, University of Heidelberg, Institute for Medical Biometry and Informatics, Im Neuenheimer Feld 305, D-69 20 Heidelberg, Germany 
TABLE I . Listing of active participants per country.
$A U-$ Austria

$\begin{array}{llc}\text { St. Pölten } & \text { Dr. Hildegard Luka (CC) } & \text { late } \\ \text { Graz } & \text { Dr. Andrea Langmann } & \text { late } \\ \text { Linz } & \text { Ass. Dr. Andreas Hajek } & \text { late } \\ \text { Salzburg } & \text { OAe Dr. Helga Thaller-Antlanger } & \text { late } \\ \text { Wien Hanusch-Krh. } & \text { Univ. Doz. Dr. S. Harrer } & \text { late } \\ \text { Wien II. Uni-Augenklinik } & \text { Prof. Dr. Arnulf Thaler } & \text { early } \\ \text { Wien Wilhelminenspital } & \text { Prof. Dr. Arnulf Thaler } & \text { early } \\ \text { Wiener Neustadt } & \text { Dr. Rudolf Pelz } & \text { late }\end{array}$

$B-$ Belgium

Bruxelles

Prof. M. Spiritus (CC)

early

Dr. Evens

early

$\mathrm{CH}-$ Switzerland

Lausanne

Dr. Giorgio Klainguti (CC)

early

Zürich

Dr. Klara Landau

early

D-Germany
Halle

Heidelberg

Berlin Charité

Berlin Steglitz

Dresden

Erlangen

Frankfurt/M. Uni

Freiburg Uni

Hamburg Uni

Homburg/Saar

Köln Uni

München TU

München Uni

Regensburg Uni

F-France

Lyon

Dr. Bourron-Madignier (CC)

early

GB - Great Britain

Liverpool

Dr. Ian Marsh

early

London H.F. Sick Children

Dr. Chris Timms

early

I-Italy

Firenze

Sassari

Prof. Dr. Riccardo Frosini (CC)

late

Prof. Dr. Francesco Carta

late

$N$ - Norway

Bergen

Aalesund

Dr. Olav H. Haugen (CC)

early

Dr. Geir Hanken

late

Dr. Leif Steene Eriksen

late

Dr. John Bore

early

Haugesund

Dr. Tore Bulie

Dr. Hans Petter Brinck

late

late

early

late

late

early

late

late

late

late

late

late

Lillehammer

Tonsberg late

late 


\begin{tabular}{llc}
\hline$N L-$ Netherlands & & \\
Amsterdam & Dr. L. Wenniger-Prick (CC) & early \\
Goes & Dr. A.G. Tjiam & early \\
Rotterdam Akademisch Z. & PD Dr. H.J. Simonsz & late \\
Rotterdam Oogziekenhuis & Dr. Jonathan de Faber & early \\
& & \\
$S-$ Sweden & & \\
Huddinge & Drs. Holmstroem/Lennerstrand (CC) & late \\
Boras & Dr. Gunnar Ladenvall & late \\
Danderyd & Dr. Agneta Wallin & late \\
Eskilstuna & Dr. Peter Furuskog & early \\
Jönköping & Dr. Brigitta Sunngvist & early \\
Linköping & Dr. Peter Jakobsson & early \\
Sundsvall & Dr. Marlene Lindberg & late \\
Umeå & Dr. Kent Johansson & early \\
Vaexjö & Dr. Invar Axelsson & late \\
& & \\
$T-T u r k e y$ & & \\
Istanbul Beyoglu & Dr. Birsen Acar (CC) & late \\
Adana & Dr. Guelhanim Haciyakupoglu & late \\
Ankara Hacettepe Univ. & Prof. Dr. Ali Sefik Sanac & early \\
Ankara Saglik Bakanligi & Dr. Saniye Demirci & early \\
Edirna Trakya Univ. & Dr. Nazan Erda & late \\
Izmir 9 Eyuel Univ. & Dr. Ayse Tulin Berk & early \\
\hline
\end{tabular}

Goes

Rotterdam Akademisch Z

$S$ - Sweden

Huddinge

Danderyd

Eskilstuna

Sundsval

Umeå

$T$ - Turkey

Istanbul Beyoglu

Ankara Saglik Bakanligi

Edirna Trakya Univ.

Dr. Ayse Tulin Berk early

early

late

late

early

late

late

early

early

early

The active participants are listed in Table $\mathrm{I}$, including one clinic with preliminary registrations only. For each country, the country coordinating clinic with country coordinator is listed first (marked with $\mathrm{CC}$ ), followed by the other clinics in alphabetical order. Each entry consists of the clinic's name, the name of the clinic coordinator, and the assigned therapy group.

\section{Patient enrolment}

2. I Planned and actual patient Recruitment According to the revised schedule, 380 patients must be recruited per group on December 3 Ist, I995. However, until I5th of April only 223 children have been recruited in the late and I4I in the early surgery group (see Fig. I). The proportion of 223 to I4I children fits exactly the proportion of 33 to 22 active clinics. In addition there are I I preliminarily registered children who still await definite entry to the study.

Until December 3Ist, 1995, in all likelihood, there will at least be recruited 200 children in the early and 300 children in the late group. This will be sufficient to reach the main goal of the study: to assess in a confirmatory analysis whether early or late surgery is preferable concerning binocular vision. Whether the study will be able to answer this question in regard to angle of strabismus and amblyopia remains uncertain, however.

Details will be discussed during the next meeting of the Study Committee in Cambridge, in September I995, during the ESA conference, to which all Country Coordinators, their representatives or other participants are invited. Possible actions could be (I) extending the recruitment period, (2) concen- 
Fig. I. Planned and actual patient recruitment. The number of 373 planned patients per group was determined according to the original schedule.

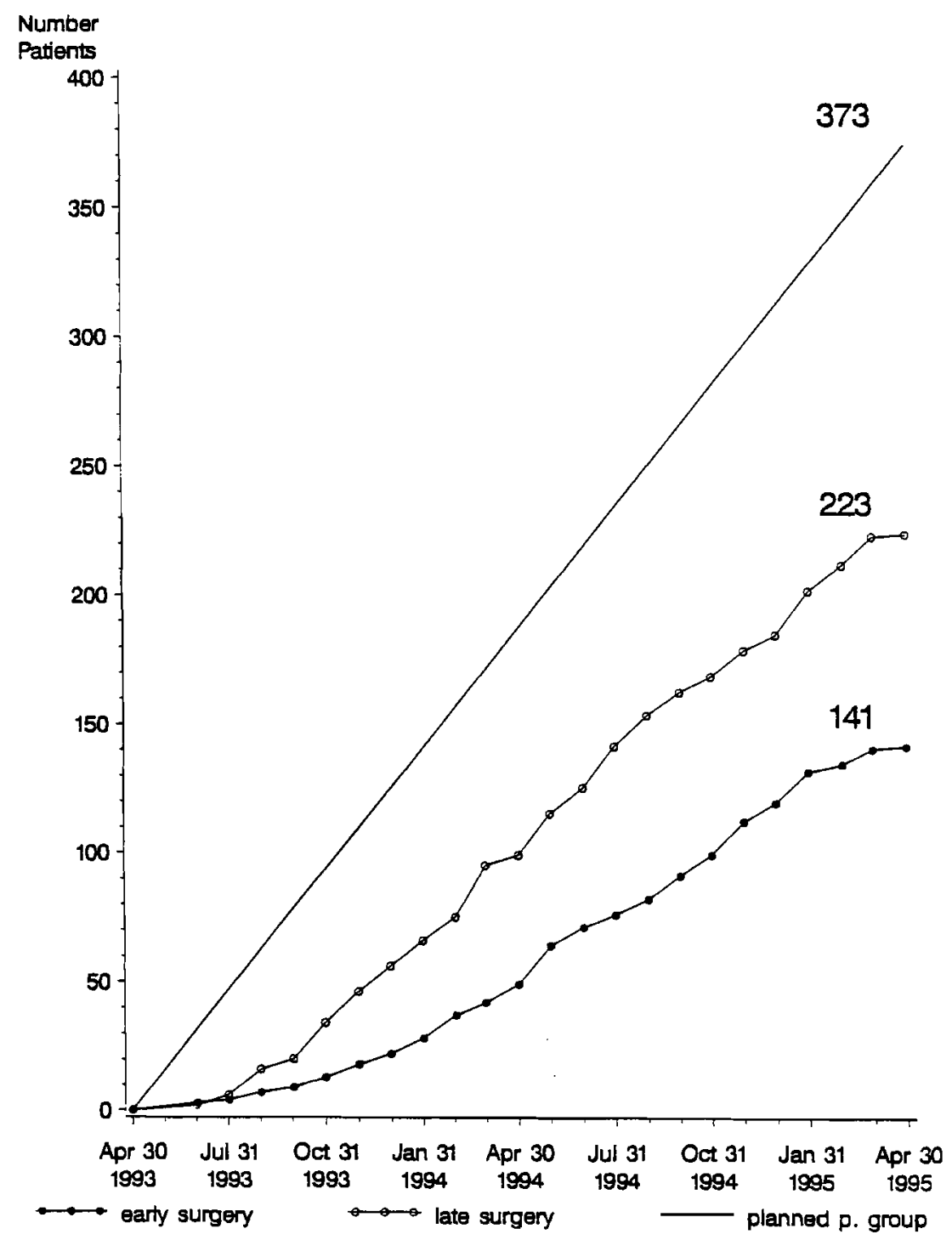

trating on binocular vision as the main criterion of the study while angle of strabismus and amblyopia are examined in an exploratory analysis only and (3) no action, accepting the loss in power associated with a lower sample size than intended.

2.2 Patients entered and patients ExCluded Per Clinic Table 2 gives an overview of patients entered and excluded per clinic. The columns contain the number of patients entered into the study and the number of patients excluded, for early and late surgery, respectively.

As in last year's report, the ratio of entered to excluded children varies considerably per clinic. For all clinics, however, the ratio is very similar with I4I:I I 5 for the early and 223:I 78 for the late surgery group.

2.3 LISTING OF EXCLUSION CRITERIA EMPLOYED EXcluded patients did not enter the study for the reasons listed in Table 3 (multiple reasons possible). 


\begin{tabular}{|c|c|c|c|c|}
\hline Clinic & $\begin{array}{l}\text { Entered early } \\
\text { surgery }\end{array}$ & $\begin{array}{l}\text { Entered late } \\
\text { surgery }\end{array}$ & $\begin{array}{l}\text { Excluded } \\
\text { early surgery }\end{array}$ & $\begin{array}{l}\text { Excluded } \\
\text { late surgery }\end{array}$ \\
\hline \multicolumn{5}{|l|}{$A U-A u s t r i a$} \\
\hline Graz & o & 6 & o & $\mathbf{I}$ \\
\hline Linz & o & 3 & 0 & 6 \\
\hline Salzburg & o & 3 & o & 2 \\
\hline St. Pölten & o & I5 & o & 13 \\
\hline Wien Hanusch-Krh. & o & I5 & o & 17 \\
\hline Wien II. Uni-Augenklinik & 9 & o & I9 & o \\
\hline Wien Wilhelminenspital & 9 & o & I4 & o \\
\hline Wiener Neustadt & o & I4 & o & 8 \\
\hline \multicolumn{5}{|l|}{$B-$ Belgium } \\
\hline Bruxelles & 27 & o & 8 & o \\
\hline Edegem & I & o & 2 & o \\
\hline \multicolumn{5}{|l|}{ CH - Switzerland } \\
\hline Lausanne & IO & o & I 2 & o \\
\hline Zürich & 2 & o & 3 & o \\
\hline \multicolumn{5}{|l|}{$D-$ Germany } \\
\hline Berlin Charité & 5 & o & 9 & o \\
\hline Berlin Steglitz & o & 2 & 0 & 3 \\
\hline Dresden & o & 7 & 0 & I6 \\
\hline Erlangen & 0 & 22 & o & I3 \\
\hline Frankfurt/M. Uni & 13 & 0 & I2 & 0 \\
\hline Freiburg Uni & 0 & 25 & o & 14 \\
\hline Halle & 0 & I & 0 & 0 \\
\hline Hamburg & $\mathrm{o}$ & I I & o & 4 \\
\hline Heidelberg & o & I9 & o & 9 \\
\hline Homburg/Saar & 0 & 4 & o & $2 \mathrm{I}$ \\
\hline Köln & o & 5 & o & 2 \\
\hline München TU & 0 & 2 & o & o \\
\hline München Uni & o & 13 & o & 3 \\
\hline Regensburg Uni & 0 & I 2 & o & I \\
\hline \multicolumn{5}{|l|}{$F-$ France } \\
\hline Lyon & 20 & o & 7 & $\mathrm{o}$ \\
\hline \multicolumn{5}{|l|}{ GB - Great Britain } \\
\hline \multirow{2}{*}{$\begin{array}{l}\text { Liverpool } \\
\text { London H.F. Sick Children }\end{array}$} & o & 0 & I & 0 \\
\hline & I & 0 & o & o \\
\hline$I-$ Italy & $\mathbf{I}$ & $\mathbf{0}$ & $\mathbf{I}$ & $\mathbf{0}$ \\
\hline \multirow{2}{*}{$\begin{array}{l}\text { Firenze } \\
\text { Sassari }\end{array}$} & 0 & 3 & 0 & 9 \\
\hline & o & 2 & 0 & o \\
\hline$N-$ Norway & $\mathbf{o}$ & 5 & $\mathbf{0}$ & 9 \\
\hline \multicolumn{5}{|l|}{ Aalesund } \\
\hline Bergen & 0 & 0 & o & 1 \\
\hline Forde Sentralsjukehuset & I I & 0 & I & 0 \\
\hline Haugesund & o & 3 & o & o \\
\hline Lillehammer & 5 & o & o & o \\
\hline \multirow{3}{*}{ Tonsberg } & o & 2 & o & $\mathrm{o}$ \\
\hline & 0 & 5 & 0 & 8 \\
\hline & I6 & IO & $\mathbf{I}$ & 9 \\
\hline
\end{tabular}

TABLE 2. Entered and excluded children per clinic. 


\begin{tabular}{|c|c|c|c|c|}
\hline Clinic & $\begin{array}{c}\text { Entered early } \\
\text { surgery }\end{array}$ & $\begin{array}{c}\text { Entered late } \\
\text { surgery }\end{array}$ & $\begin{array}{c}\text { Excluded } \\
\text { early surgery }\end{array}$ & $\begin{array}{c}\text { Excluded } \\
\text { late surgery }\end{array}$ \\
\hline \multicolumn{5}{|l|}{ NL - Netherlands } \\
\hline Amsterdam & 2 & o & I & o \\
\hline Rotterdam Akademisch Z. & 0 & 2 & o & 9 \\
\hline \multirow[t]{2}{*}{ Rotterdam Oogziekenhuis } & 4 & o & 16 & 0 \\
\hline & 6 & 2 & 17 & 9 \\
\hline \multicolumn{5}{|l|}{$S-S w e d e n$} \\
\hline Boras & o & I & o & 2 \\
\hline Danderyd & o & 6 & o & o \\
\hline Eskilstuna & I & 0 & I & 0 \\
\hline Huddinge & o & $\mathbf{I}$ & o & o \\
\hline Jönköping & 6 & 0 & 2 & 0 \\
\hline Linkoeping & 6 & o & 2 & o \\
\hline Sundsvall & 0 & 5 & o & I \\
\hline Umeå & 3 & 0 & o & 0 \\
\hline \multirow[t]{2}{*}{ Vaexjö } & o & 4 & 0 & o \\
\hline & I6 & 17 & 5 & 3 \\
\hline \multicolumn{5}{|l|}{$T-$ Turkey } \\
\hline Adana & 0 & 2 & o & o \\
\hline Anakara Hacettepe Univ. & I & o & 4 & 0 \\
\hline Ankara Saglik Bakanligi & 2 & o & o & o \\
\hline Edime Trakya Univ. & 0 & 8 & o & 13 \\
\hline Istanbul Beyoglu & o & o & o & 2 \\
\hline \multirow[t]{2}{*}{ Izmir 9 Eyuel Univ. } & 3 & 0 & I & 0 \\
\hline & 6 & Io & 5 & 15 \\
\hline All Clinics & I4I & 223 & 115 & 178 \\
\hline
\end{tabular}

TABLE 3. Listing of exclusion criteria employed

\begin{tabular}{lc}
\hline Reason & Frequency \\
\hline Age limit & 15 \\
Onset of strabismus after the age of four months & 90 \\
Prematurity & 17 \\
Congenital nystagmus & 28 \\
Cerebral palsy or other neurological deficit & 58 \\
Angle of strabismus $<5^{\circ}$ & 19 \\
Angle of strabismus $>30^{\circ}$ & 40 \\
Divergent strabismus & 4 \\
& \\
No exclusion criteria apply but parents declined & 4 \\
to participate & \\
& \\
Other medical reasons (e.g., tachycardia) & 8 \\
Organizational reasons (e.g., language problems) & 4 \\
Formal reasons (e.g., application after surgery) & 70 \\
\hline
\end{tabular}

2.4 DELAY BETWEEN ENTRY EXAMINATION AND PATIENT REGISTRATION Last year, we reported on the problem of long delays between entry examination and registration of the patient. The situation has improved since. $40 \%$ (23\% last year) of all children are registered within a 


\begin{tabular}{|c|c|c|c|c|c|}
\hline Clinic & Complete & $\begin{array}{c}\text { Returned } \\
\text { for } \leq 4 \\
\text { weeks }\end{array}$ & $\begin{array}{c}\text { Due for } \\
\text { for } \leq 4 \\
\text { weeks }\end{array}$ & $\begin{array}{c}\text { Returned } \\
\text { for }>4 \\
\text { weeks }\end{array}$ & $\begin{array}{c}\text { Due for } \\
>4 \\
\text { weeks }\end{array}$ \\
\hline \multicolumn{6}{|l|}{$A U-$ Austria } \\
\hline Graz & 17 & & $\mathbf{I}$ & 3 & 3 \\
\hline Linz & 9 & & & & \\
\hline Salzburg & 7 & & & I & \\
\hline St. Pölten & 56 & & & & \\
\hline Wien Hanusch-Krh. & 38 & & & & \\
\hline Wien II. Uni-Augenklinik & 39 & & & I & 2 \\
\hline Wien Wilhelminenspital & 48 & $\mathbf{I}$ & & & I \\
\hline Wiener Neustadt & 48 & & & & \\
\hline & 262 & $\mathbf{I}$ & $\mathbf{I}$ & 5 & 6 \\
\hline \multicolumn{6}{|l|}{$B-$ Belgium } \\
\hline Bruxelles & 87 & & 7 & & 12 \\
\hline Edegem & 2 & & & I & \\
\hline \multicolumn{5}{|l|}{ CH - Switzerland } & 12 \\
\hline Lausanne & 38 & & & & \\
\hline Zürich & 6 & & I & & \\
\hline \multicolumn{6}{|l|}{$D-$ Germany } \\
\hline Berlin Charité & $2 \mathrm{I}$ & $\mathbf{I}$ & & & I \\
\hline Berlin Steglitz & 5 & & & & I \\
\hline Dresden & $2 \mathrm{I}$ & I & & & \\
\hline Erlangen & 62 & & 3 & & I7 \\
\hline Frankfurt/M. Uni & 56 & & 2 & & \\
\hline Freiburg Uni & 82 & & & & $\mathrm{I}$ \\
\hline Halle & 3 & & & & I \\
\hline Hamburg & 28 & I & & I & \\
\hline Heidelberg & 56 & & 3 & & I I \\
\hline Homburg/Saar & IO & & & & \\
\hline Köln & I I & $\mathbf{I}$ & I & & \\
\hline München TU & 5 & & & & \\
\hline München Uni & $5 I$ & I & & & 3 \\
\hline Regensburg Uni & $4 \mathrm{I}$ & & & & 3 \\
\hline$F-$ France & 452 & 5 & 9 & $\mathbf{I}$ & 38 \\
\hline Lyon & 57 & I & 3 & & \\
\hline \multicolumn{6}{|l|}{$G B-G r e a t$ Britain } \\
\hline Liverpool & & & & & 3 \\
\hline London H. F. Sick Chìldren & & & & & 3 \\
\hline \multicolumn{6}{|l|}{$I-$ Italy } \\
\hline Firenze & 2 & & I & 4 & 6 \\
\hline Sassari & 4 & & & & \\
\hline \multicolumn{6}{|l|}{$N-$ Norway } \\
\hline \multicolumn{6}{|l|}{ Aalesund } \\
\hline \multicolumn{6}{|l|}{ Bergen } \\
\hline Forde Sentralsjukehuset & $\begin{array}{c}32 \\
9\end{array}$ & & $\begin{array}{l}5 \\
1\end{array}$ & I & 11 \\
\hline Haugesund & $2 \mathrm{I}$ & & & 3 & I \\
\hline \multirow{3}{*}{$\begin{array}{l}\text { Lillehammer } \\
\text { Tonsberg }\end{array}$} & 3 & & & & 3 \\
\hline & 16 & I & & $\mathbf{I}$ & I \\
\hline & 8I & $\mathbf{I}$ & 6 & 6 & 16 \\
\hline
\end{tabular}

TABLE 4. State of documentation form per clinic 


\begin{tabular}{|c|c|c|c|c|c|}
\hline Clinic & Complete & $\begin{array}{c}\text { Returned } \\
\text { for } \leq 4 \\
\text { weeks }\end{array}$ & $\begin{array}{c}\text { Due for } \\
\text { for } \leq 4 \\
\text { weeks }\end{array}$ & $\begin{array}{c}\text { Returned } \\
\text { for }<4 \\
\text { weeks }\end{array}$ & $\begin{array}{c}\text { Due for } \\
<4 \\
\text { weeks }\end{array}$ \\
\hline \multicolumn{6}{|l|}{$N L-N e t h e r l a n d s$} \\
\hline Amsterdam & 3 & & & I & \\
\hline Rotterdam Akademisch Z. & 9 & & I & & \\
\hline \multirow[t]{2}{*}{ Rotterdam Oogziekenhuis } & 2 & & & & 7 \\
\hline & 14 & $\mathbf{0}$ & $\mathbf{I}$ & $\mathbf{r}$ & 7 \\
\hline \multicolumn{6}{|l|}{$S-S w e d e n$} \\
\hline Boras & 2 & & & & I \\
\hline Danderyd & 14 & & 1 & I & 5 \\
\hline Eskilstuna & 5 & & & & \\
\hline Huddinge & 3 & & & I & \\
\hline Jönköping & 28 & 2 & & & I \\
\hline Linköping & 20 & I & I & & 2 \\
\hline Sundsvall & I5 & & 2 & I & I \\
\hline Umeå & 14 & & I & & \\
\hline \multirow[t]{2}{*}{ Vaexjö } & I I & I & & I & 4 \\
\hline & $\mathbf{I I 2}$ & 4 & 5 & 4 & 14 \\
\hline \multicolumn{6}{|l|}{$T-$ Turkey } \\
\hline Adana & I & I & I & I & 2 \\
\hline Ankara Hacettepe Univ. & & & & 2 & 2 \\
\hline Ankara Sglik Bakanligi & 5 & & & & I \\
\hline $\begin{array}{l}\text { Edirne Trakya Univ. } \\
\text { Istanbul }\end{array}$ & 18 & & & & 2 \\
\hline \multirow[t]{2}{*}{ Izmir 9 Eyuel Univ. } & 3 & & & 3 & 4 \\
\hline & 27 & $\mathbf{I}$ & $\mathbf{I}$ & 6 & II \\
\hline All Clinics & 1144 & $\mathbf{1 3}$ & 35 & 28 & II3 \\
\hline
\end{tabular}

week and $77 \%$ (45\% last year) within four weeks after the entry examination, which is still in accordance with the protocol (The Early vs. Late Infantile Strabismus Surgery Study Group, 1993).

3 Quality of the documentation Tables 4 and 5 summarize the completeness of the documentation forms and of the data. The plausibility is permanently monitored by the study center.

Table 4 lists all documentation forms into one of five categories. 'Complete' means that the forms are without error. 'Due' means that the forms should become available to the study center shortly. There can be various reasons for this to happen, for instance a delay in the examination procedure or an internal organizational problem. 'Returned' means that the forms have been returned for completion or for correction of plausibility errors. The number of forms per clinic in each category is listed in the table.

Table 5 displays the percentage of completeness of the required data among all documentation forms. All forms that are available to the study center were included in this part of the analysis, regardless of whether they were 'complete' or 'returned'. Interdependencies in the data are taken into account: For instance, occlusion patterns should only be noted in the form if the question 'previous occlusion therapy?' has been answered affirmatively. 


\begin{tabular}{|c|c|c|c|}
\hline Country Clinic & $\begin{array}{l}\text { Entry examination } \\
\text { form }\end{array}$ & Examination form & Surgery form \\
\hline \multicolumn{4}{|l|}{$A U-$ Austria } \\
\hline Graz & IOO & 99 & \\
\hline Linz & IOO & 99 & \\
\hline Salzburg & IOO & 98 & \\
\hline St. Pölten & IOO & 100 & \\
\hline Wien Hanusch-Krh. & IOO & 100 & \\
\hline Wien II. Uni Augenklinik & IOO & 94 & 100 \\
\hline Wien Wilhelminenspital & IOO & 97 & IOO \\
\hline Wiener Neustadt & IOO & IOO & \\
\hline \multicolumn{4}{|l|}{$B-$ Belgium } \\
\hline Bruxelles & IOO & 100 & 95 \\
\hline Edegem & IOO & IOO & 80 \\
\hline \multicolumn{4}{|l|}{$C H-$ Switzerland } \\
\hline Lausanne & IOO & 99 & 100 \\
\hline Zürich & 100 & 100 & IOO \\
\hline \multicolumn{4}{|l|}{$D-$ Germany } \\
\hline Berlin Charité & 98 & IOO & IOO \\
\hline Berlin Steglitz & 100 & IOO & \\
\hline Dresden & IOO & 99 & \\
\hline Erlangen & IOO & IOO & \\
\hline Frankfurt/M. Uni & IOO & 98 & 94 \\
\hline Freiburg Uni & 99 & 100 & \\
\hline Halle & 100 & 100 & \\
\hline Hamburg & IOO & 97 & \\
\hline Heidelberg & IOO & I00 & \\
\hline Homburg/Saar & IOO & IOO & \\
\hline Köln & 98 & 99 & \\
\hline München TU & IOO & 100 & \\
\hline München Uni & IOO & 100 & 100 \\
\hline Regensburg Uni & 98 & 99 & \\
\hline \multicolumn{4}{|l|}{$F$ - France } \\
\hline Lyon & 100 & 99 & 96 \\
\hline \multicolumn{4}{|l|}{$G B-$ Great Britain } \\
\hline \multicolumn{4}{|l|}{ Liverpool } \\
\hline \multicolumn{4}{|l|}{ London H. F. Sick Children } \\
\hline \multicolumn{4}{|l|}{$I-I t a l y$} \\
\hline Firenze & 92 & 90 & \\
\hline Sassari & 100 & 100 & \\
\hline \multicolumn{4}{|l|}{$N-$ Norway } \\
\hline \multicolumn{4}{|l|}{ Aalesund } \\
\hline Bergen & IOo & 99 & IOO \\
\hline Forde Sentralsjukehuset & 100 & 99 & \\
\hline Haugesund & IOO & 99 & 100 \\
\hline Lillehammer & IOO & 100 & \\
\hline Tonsberg & 95 & 98 & \\
\hline
\end{tabular}

TABLE 5. Percentage of completeness of required data per clinic 


\begin{tabular}{|c|c|c|c|}
\hline Country Clinic & $\begin{array}{l}\text { Entry examination } \\
\text { form }\end{array}$ & Examination form & Surgery form \\
\hline \multicolumn{4}{|l|}{ NL - Netherlands } \\
\hline Amsterdam & IOO & 96 & \\
\hline Rotterdam Akademisch Z. & 100 & 100 & \\
\hline Rotterdam Oogziekenhuis & IOO & 100 & \\
\hline \multicolumn{4}{|l|}{$S-S w e d e n$} \\
\hline Boras & 100 & 100 & \\
\hline Danderyd & 98 & 99 & \\
\hline Eskilstuna & IOO & 100 & IOO \\
\hline Huddinge & IOO & 94 & \\
\hline Jönköping & 98 & 100 & 100 \\
\hline Linköping & 100 & 99 & 100 \\
\hline Sundsvall & IOO & 95 & \\
\hline Umeå & IOO & 99 & 100 \\
\hline Vaexjö & 97 & 93 & \\
\hline \multicolumn{4}{|l|}{$T-$ Turkey } \\
\hline Adana & 95 & 58 & \\
\hline Ankara Hacettepe Univ. & IOO & IOO & \\
\hline Ankara Saglik Bakanligi & IOO & IOO & \\
\hline $\begin{array}{l}\text { Edirne Trakya Univ. } \\
\text { Istanbul }\end{array}$ & 100 & 100 & \\
\hline 9 Eyuel Univ. & 96 & 100 & \\
\hline All Clinics & 99 & 99 & 98 \\
\hline
\end{tabular}

\section{Dropouts and deviations of therapy}

4. I DROPOUTS In total eight children have been lost to follow-up, three in the early and five in the late operating group. In one case the child and parents had moved, in seven cases the parents were no longer compliant.

4.2 SURGERY SCHEDULE Surgery should be performed before the child's second birthday in the early operating group, and after its 32 nd month in the late group.

In the early group, 54 children have been operated in accordance with the study protocol. For I 3 children, no surgery is documented although they are already two years old. Four children have definitively been operated too late. Among these 17 children, two could not be operated as scheduled because the child was ill, in three other cases the childrens' parents opted for late surgery.

In the late group, one child has been operated up to now. It did not complete its 32 nd month of life, however.

4.3 EXAMINATION INTERVALS Intermediate examinations should be performed every six months with a maximum delay of four weeks. 328 out of 356 documented examinations have been performed accordingly. The longest delays were I I or I 2 months in three cases. Intermediate examinations should also be performed within two weeks after surgery, with a tolerance of two weeks. This has been achieved in $5 \mathrm{I}$ of 63 cases of surgery (including four cases of re-operation). Furthermore, five examinations were done 


\begin{tabular}{lcc}
\hline Variable & Early & Late \\
& surgery & surgery \\
\hline Mean of occlusion pretreatment in months & 2.2 & $\mathrm{I} .9$ \\
Median of occlusion pretreatment in months & 0 & 0 \\
Third quartile of occlusion pretreatment & 4 & 3 \\
Mean age in days at the moment of the entry examinaton & 346 & 328 \\
Rate of previously prescribed glasses & $21 \%$ & $23 \%$ \\
Rate of previously prescribed atropine & $2 \%$ & $3 \%$ \\
Rate of permanent occlusion tolerance & $79 \%$ & $78 \%$ \\
Rate of vertical deviation in primary position & $6 \%$ & $15 \%$ \\
Rate of vertical deviation in left or right gaze & $25 \%$ & $34 \%$ \\
Rate of V-pattern $>5$ degrees & $2 \%$ & $8 \%$ \\
Rate of A-pattern & $\mathrm{I} \%$ & $2 \%$ \\
Rate of latent nystagmus & $\mathrm{II} \%$ & $33 \%$ \\
Rate of torticollis & $8 \%$ & $19 \%$ \\
Rate of DVD & $6 \%$ & $\mathrm{I} 5 \%$ \\
\hline
\end{tabular}

within the second month after surgery. In seven cases, no postoperative examination is documented at the study center.

5 Prognostic factors To ensure the internal validity of the study's results, prognostic factors should be distributed homogeneously in the early and late surgery groups. With respect to external validity, it is also desired that the distribution of the samples (entered children) is the same as in the population. Therefore, excluded children are also documented. Details about important prognostic factors are reported below.

RETINOSCOPY VALUES The spherical equivalents of the worse eye in the early and the late group followed a unimodal distribution, both with a median of Sph. +2. Values ranged from -0.5 to 6 in the early group and from -4.5 to 7 in the late group. The wider range in the late group is not alarming since there are more patients in this group. Excluded children also have a unimodal distribution with the same median of $\mathrm{Sph} .+2$, but with values ranging from - I I to 30 .

HORIZONTAL ANGLE OF SQUINT The range is limited by the exclusion criteria from 5 to 30 degrees. The median values were 2I degrees in the early and 20 degrees in the late surgery group. Excluded children had a median of 17 degrees with extreme values of -25 and 50 degrees.

DEGREE OF AMBLYOPIA OF THE WORSE EYE The distributions were similiar for all groups. The most frequent category was 2 (alternating but preference of fixation). Forty-five percent of the early surgery and $49 \%$ of late surgery children, as well as $36 \%$ of excluded children fell into this category. The proportion of children within categories I to 3 was $9 \mathrm{I} \%$ in the early and $97 \%$ in the late group as compared to $83 \%$ in the excluded group (categories I to 3 are prognostically better than 4 and 5).

RESTRICTION OF ABDUCTION OF THE WORSE EYE Distributions were similar. The most frequent category was I (free, using pursuit movements), the second was 3 (passing midline but not free, using any method). Catego- 
ries I and 2 applied to $62 \%, 56 \%$ and $60 \%$ for early, late and excluded children, respectively.

A summary of the distribution of other variables is presented in Table 6.

\section{References}

The Early vs Late Infantile Strabismus Surgery Study Group. The protocol for the Early vs. Late Infantile Strabismus Surgery Study. Strabismus I993; I:I35-I57.

The Early vs. Late Infantile Strabismus Surgery Study Group. The Early vs. Late Infantile Strabismus Surgery Study: First monitoring report. Strabismus 1994; 2:87I02. 